\title{
SPATIAL DISTRIBUTION BEHAVIOR OF BASIC POLLUTANTS IN A SUBSURFACE-FLOW WETLAND WITH THALIA GENICULATA
}

\author{
GASPAR LÓPEZ-OCAÑA¹, RAÚL G. BAUTISTA-MARGULIS, ARTURO VALDES MANZANILLA, \\ CARLOS A. TORRES-BALCAZAR, ROCÍO LÓPEZ-VIDAL, EÚNICE PÉREZ-SÁNCHEZ \& LILIANA \\ PAMPILLÓN-GONZÁLEZ ${ }^{2}$ \\ División Académica de Ciencias Biológicas, Universidad Juárez Autónoma de Tabasco, México.
}

\begin{abstract}
Constructed wetland is a technically feasible, economically viable and environmentally sustainable natural technology that contributes at reducing greenhouse gases in the wastewater treatment. In this context, a pilot-scale subsurface horizontal-flow constructed wetland (HF-CW) was evaluated by using Thalia geniculata as native vegetation. The reactor operated with an average flow rate of $204 \pm 66 \mathrm{~L} /$ day of wastewater, with gravel support medium diameter of $2.8 \pm 0.8 \mathrm{~cm}$, porosity of $\mathrm{n}=56.3 \pm 3.5$ and density of $1,666.7 \pm 119.3 \mathrm{~kg} / \mathrm{m}^{3}$, with 4.2 days as a hydraulic retention time. The HF-CW weighs approximately $2,600 \mathrm{~kg}$, considering $1,108 \mathrm{~kg}$ of gravel, $850 \mathrm{~kg}$ of water and the weight of the container (carbon steel). The kinetic behavior was observed to be first order with $\mathrm{k}=-0.43$ days $^{-1}$, favoring the efficiency of biological oxygen demand removal up to $90 \%$. During the experiments, it was shown that the bacterial biomass attached to the support material decreased its concentration from influent to effluent $(33,000$ to $2,000 \mathrm{mg} / \mathrm{kg}, \mathrm{mg}$ of fixed biomass attached to each $\mathrm{kg}$ of gravel). For the electrical conductivity, color and turbidity, values were found to decrease in the order of $7.2 \pm 4.8 \%, 86.7 \pm 6.8 \%$ and $90.3 \pm 5.8 \%$, respectively. From the current experimental results, it was demonstrated that constructed wetlands, involving native species as vegetation, are highly efficient for the removal of basic pollutants. Keywords: Constructed wetlands, macrophytes, removal efficiency, wastewater treatment.
\end{abstract}

\section{INTRODUCTION}

Wastewater treatment based on biological processes such as aerobic lagoons, maturation and facultative ponds, constructed wetlands (CWs) and aquatic crops represents a sustainable technological option for small and medium communities due to its high efficiency in pollutant removal, low operating cost and easy maintenance and construction. Moreover, the use of effluents from CW not only represents a source of water, but also is a potential source of nutrient input, with economic and environmental benefits; thus, it has acquired significant relevance across the globe. So, the selection of the type of wastewater treatment employing natural methods depends on the final objectives of the process [1].

The CW technology for domestic wastewater treatment is based on the association of bacteria with vegetation as the bacteria degrade organic matter, accumulate minerals and nutrients and convert them into biomass easy to harvest on the surface, which can be later used as an excellent source of protein, fertilizer or energy [2]. Also, the interaction with different natural depuration processes such as physical, chemical and biological contributes to the stabilization of the concentrations and the type of pollutants having less energy dissipation, low waste production, low environmental impact and simple operation [3-5].

The subsurface horizontal-flow constructed wetlands (HF-CWs) consist of a channel or pit, in the bottom, and has been placed a water-impermeable material, which can be plastic or a soil with low permeability. The channel of the HF-CW is filled with a porous substrate

${ }^{1}$ Main author: https://orcid.org/0000-0002-8402-8160

${ }^{2}$ Corresponding author: http://orcid.org/0000-0003-0216-700X 
(e.g. soil or gravel) to support the growth of emerging aquatic plants (reeds, rushes, tule, etc.). The pretreated wastewater flows by gravity and along (horizontally) through the substrate, promoting the interaction of facultative microorganism that lives in the roof of the plant with the biomass adhered in the substrate. The depths in the subsurface flow reactor, generally, are less than $0.6 \mathrm{~m}$ and the water level is between 2 and $4 \mathrm{~cm}$ below the surface of the substrate [6].

A recent research involves the design of HF-CW using two beds of cane species (Phragmites $s p$.) and a pretreatment through a stabilization lagoon, obtaining as a result of the pollutant removal of wastewater from heavy oil production, up to $81 \%$ of Chemical Oxygen Demand (COD), and $89 \%$ of Biochemical Oxygen Demand $\left(\mathrm{BOD}_{5}\right)$, in a hydraulic retention time (HRT) of 3 days [7].

In the construction and evaluation of an experimental vertical-flow $\mathrm{CW}$ (VF-CW) prototype, a culture of bacteria, fungi and actinomycetes was used. The total of microorganism was determined by plate count method according to APHA (1989), and the urease activity was determined by colorimetric analysis demonstrating that there is a significant correlation between substrate microorganism and urease activity in CW. It was concluded that urease plays a key factor in the depuration process and can be taken as an indicator in the removal of pollutant such

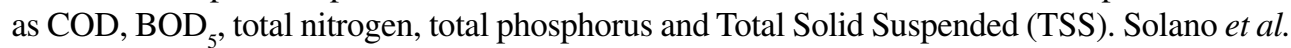
[24] built an experimental prototype HF-CW with species such as torota (Thypa sp.) and cane (Phragmites sp.). The torota showed a better density and efficiency with respect to the cane [8].

When the quality of treated water was evaluated through an HF-CW in series employing reed vegetation (Scirpus americanus), enea (Typha domingensis) and water lily (Eichhornia crassipes), a decrease in chemical parameters such as $\mathrm{pH}, \mathrm{COD}(71 \%)$, calcium (91\%), chloride $(77 \%)$, nitrite $(82 \%)$, ammonium $(99.9 \%)$ and phosphate $(77 \%)$, with the exception of the nitrate ion (36\%) and the electrical conductivity that increased by $93 \%$ [9]. In that experiment, the system was stabilized for 44 days, with a retention time of 15 days in each CW.

A study [10] compared contaminant removal with and without supplemental aeration using Phragmites australis and effluents from the textile industry, where higher removal rates were observed by adding oxygen to obtain $98 \%$ in color, $86 \%$ COD, $67 \%$ in Total Kjeldahl Nitrogen (TKN), $26 \%$ in PT, $96 \%$ in $\mathrm{NH}_{4}-\mathrm{N}$ and $86 \% \mathrm{NO}_{3}-\mathrm{N}$. Another study treats leachate from olive pomace using a VF-CW obtaining $\mathrm{pH}$ value of 8.5 and removals of $86 \%, 45 \%$ and $77 \%$ of COD, Electrical Conductivity (CE) and color, respectively. The effluent of these treatments was putted through an electrochemical oxidation that improved the quality of the effluent but increased the eco-toxicity in it [11].

Mexico is a vast country with a variety of geographical, hydrological and climate conditions. Particularly, in Tabasco, a state located in the south of Mexico (coordinates $17^{\circ} 15^{\prime}-$ $18^{\circ} 39^{\prime} \mathrm{N} ; 91^{\circ} 00^{\prime}-94^{\circ} 17^{\prime} \mathrm{W}$ ), the most important rivers around the country takes places. Unfortunately, most of the water that reaches the rivers does not fulfill the water quality for discharge. The predominant climate is humid and warm humid with monthly average temperature between $22^{\circ} \mathrm{C}$ and $28^{\circ} \mathrm{C}$ and precipitation from 1,800 to $2,500 \mathrm{~mm}$ annually. This climatic condition allows the growth of different vegetation such as Thalia geniculate and Thypa latifolia (Fig. 1).

Thalia geniculate covers large areas in the tropical wetlands of southeastern Mexico. It is considered as one of the dominant species from the popal. It can become dry during a severe drought, leaving only the rhizome (Fig. 1). Among its characteristics, it has large ovate sheets up to $60 \mathrm{~cm}$ long and $25 \mathrm{~cm}$ wide, with a sharp end and a rounded base (Asociación Ribera Norte, 2013). In contrast, Typha latifolia is an aquatic plant herbaceous rooted emergent and perennial, up to $2.5 \mathrm{~m}$. It is considered as an asymmetric plant, with ventral epidermis and a large quantity of dark-colored mucilaginous glands, arranged longitudinally and towards the 


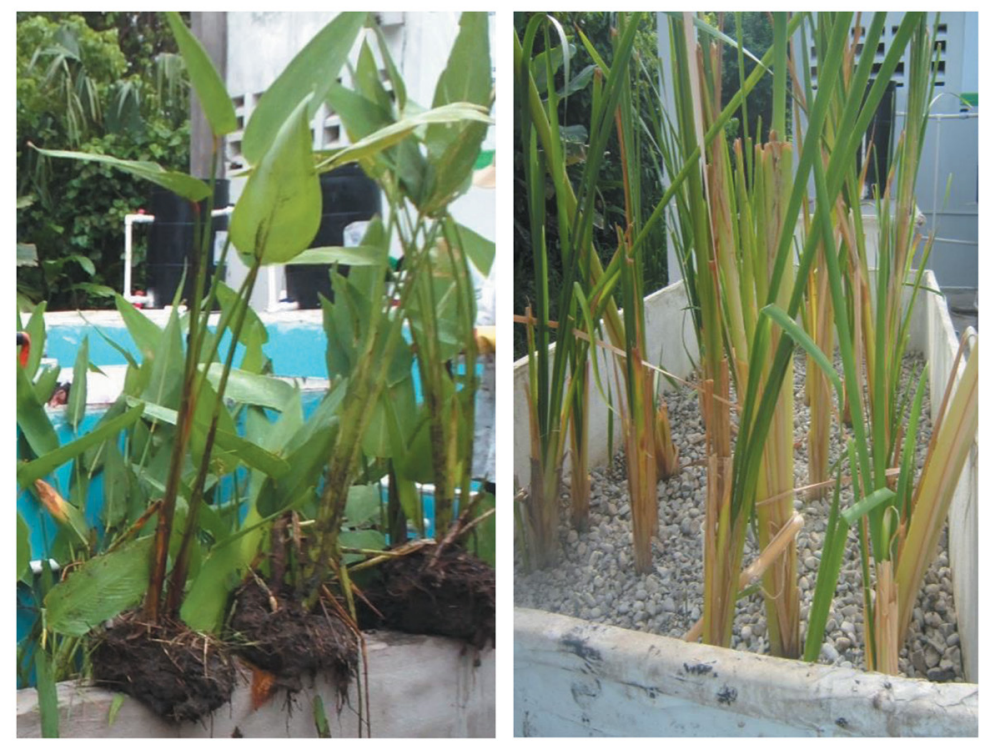

Figure 1: Native vegetation used in CW, Thalia geniculata (left) and Thypa latifolia (right).

base of the lamina, $1.5 \mathrm{~m}$ long and 8-9 $12 \mathrm{~mm}$ wide, convex below the sheet and flat towards the acute apex.

Tabasco has six CWs installed with a treatment capacity of $961.6 \mathrm{~L} / \mathrm{s}$, operating only 937.15 L/s. This quantity represents the $77.9 \%$ of the treated wastewater employing CW technology in Mexico [12]. The CW, built in Tabasco, included combined systems of free water surface CWs and HF-CW with mainly Thypa latifolia vegetation [12]. For this reason, it is necessary to generate information for waste water treatment applying economic treatments that are easy to operate and appropriate to the climatic conditions taking into account natural resources of the region. CW could play a key role for water treatment and requires little operational personnel, and during the process, elements provided by nature are involved [13]. In this context, the contribution of this research is to assess the phytoremediation potential in a $\mathrm{CW}$ using Thalia geniculate by evaluating the kinetics of degradation and the efficiency of pollutant removal. One of the advantages was the macrophytes employed, which correspond to native vegetation, instead of introduced species, promoting the valorization of species from the region of southeastern Mexico, which has not been evaluated yet.

\section{MATERIALS AND METHODS}

\subsection{Location of the pilot-scale CW}

The experimental HW-CW was installed at the Division Academica de Ciencias Biologicas (DACBiol), which is a campus from the Universidad Juarez Autonoma de Tabasco. The vegetation was collected in swampy areas from the Municipality of Centro, Tabasco.

\section{2 $\mathrm{CW}$ design characteristics}

The reactor is $2.5 \mathrm{~m}$ long $\times 1.2 \mathrm{~m}$ wide $\times 1 \mathrm{~m}$ high, operating with $0.5 \mathrm{~m}$ of support medium [14]. In the reactor, all the accessories, pipes and hydraulic connections of polyvinylide of 


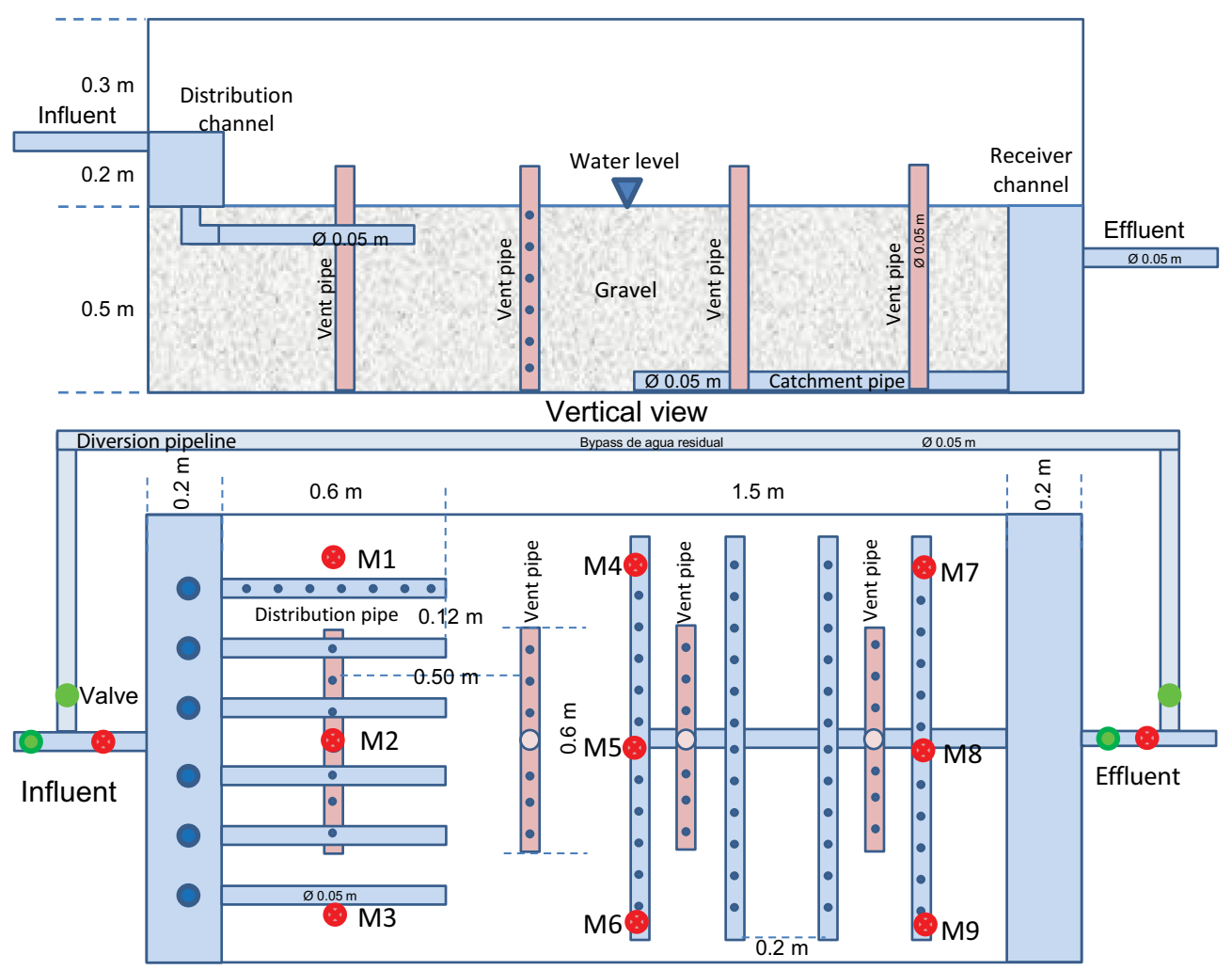

Horizontal view

Figure 2: The red points from M1 to M9 indicate the sampling point in the subsurface horizontal-flow constructed wetland (HF-CW). The effluent and effluent points were also measured.

1 inch (valves, elbows, Ts, connectors, etc.) were installed for the supply and distribution of wastewater. The water is supplied through a control tank that serves to control the speed of entry; once the water enters, it is evenly distributed by a channel of $0.2 \mathrm{~m} \times 0.2 \mathrm{~m}$, and in this channel, there are six pipeline distributions releasing the water $5 \mathrm{~cm}$ below the surface of the support medium. The water, once treated, is collected at the bottom by pipes and goes to a screen designed as a sampling point for the effluent. For natural aeration, venting wells were placed that function as internal sampling points. Finally, $50 \mathrm{~cm}$ of mixed gravel was placed in the reactor, and then, the stabilization phase of the vegetation was proceeded (Fig. 2).

\subsection{Planting and stabilization of vegetation}

The vegetation was placed into the gravel support medium. The support medium had a diameter of $2.8 \pm 0.8 \mathrm{~cm}$, porosity of $n=56.3 \pm 3.5$ and density of $1,666.7 \pm 119.3 \mathrm{~kg} / \mathrm{m}^{3}$. The stem size on the surface was $10 \mathrm{~cm}$ long and roots were placed $15 \mathrm{~cm}$ below the surface [15]. The reactor was fed with clean water at the beginning, maintaining a level of $40 \mathrm{~cm}$ of water for stabilization of the vegetation $[2,13]$. Thereafter, wastewater from the carcamus of the DACBiol was added to the CW. The stabilization phase in CW lasted 6 months from February to July 2016. By the end of October 2016, the vegetation was pruned in order to evaluate 
its growth prior to the water quality monitoring stage. The monitored variables were height, diameter of the pseudostem, perimeter, weight (initial and final), leaves (length and width) and humidity.

2.4 Hydraulic retention time, removal efficiency and degradation rate

In the reactor, a mixed gravel support medium (crushed rock from the Teapa River, southern region of Tabasco) was placed and the HRT was calculated with the operation flow of the wastewater [15].

$$
H R T=n d A / Q
$$

where $n$ is the porosity, $d$ is the height of the support medium, $A$ is the cross section of the reactor and $Q$ is the water flowrate.

The pollutant removal efficiency was calculated as follows [16], where $\eta$ represents the removal efficiency in $\%, C_{1}$ is the wastewater influent concentration and $C_{2}$ is the wastewater effluent concentration.

$$
\eta=\left[\left(C_{1}-C_{2}\right) / C_{1}\right] \times 100
$$

The behavior of wastewater is a first-order kinetic reaction, and the degradation rate $k$ was estimated with the following equation [15].

$$
K_{o}=-\ln \left(\mathrm{Cn} / \mathrm{C}_{\mathrm{o}}\right) / \tau \text {, }
$$

where $\tau=$ retention time for BOD removal, $C n=$ BOD effluent concentration of the reactor ' $n$ ' $(\mathrm{mg} / \mathrm{L}), C_{\mathrm{o}}=$ influent concentration and $\mathrm{K}_{\mathrm{o}}=$ degradation constant.

\subsection{Wastewater characterization}

The variables for the spatial distribution analysis were taken at the sampling points established in the HW-CW (Table 1, Fig. 2). Two simple samples were collected per day during 11 days. The monitoring was developed during the months of February to April 2017. For the kinetic study, the BOD in the influent and effluent of the HW-CW was monitored, being

Table 1: Wastewater method analysis for the determination of control parameters.

\begin{tabular}{ll}
\hline Parameter & $\begin{array}{l}\text { Standard Methods for the Examination of } \\
\text { Water and Wastewater (SMWW) }\end{array}$ \\
\hline Temperature & SM 2550, APHA (1992) \\
Turbidity & METHOD 180.1, EPA (2001) \\
Electrical conductivity (EC) & SM 2510B \\
pH & SM 9040B \\
Biological oxygen demand (BOD) & APPENDIX B, APHA (1998) \\
Total volatile solids (TVS) & METHOD 1684, EPA (2001) \\
Color & SM 2120B, APHA (1992) \\
\hline
\end{tabular}


a simple daily sample for 7 days. All these samples were taken after 1 year of operation. For estimating the kinetic constant $K$ in the process, the sample is taken from the influent and the effluent, obtaining the behavior and knowing the order of reaction, and here, it is considered that the influent is the input concentration of a given day and that the effluent is the concentration of exit of the reactor after having fulfilled its HRT of that same day [15].

\subsection{Biomass on the support medium}

The biomass, referring to the quantity of microorganisms on the rocks, was determined by gravimetry, adapting the total volatile solid method to a sample of the support medium at each sampling point (Fig. 2). Each sample considers the density and porosity of the system [17].

\subsection{Analysis of the distribution of pollutants}

To analyze the behavior of contaminants spatially along the length and width of the reactor, the daily average of each sampling point referring to variables such as temperature, turbidity, electric conductivity, $\mathrm{pH}$ and biomass was monitored and analyzed. The pollutant distribution inside the reactor was plotted using the software Surfer 8.0 [18], which allows the determination of the spatial distribution within a coordinate system based on a linear interpolation and a quadratic diagram (isoconcentration map).

\subsection{Statistical analysis}

In this work, an experimental design of one factor was performed for HW-CW with Thalia geniculata, with five treatments (distances 0.00, 0.42, 1.25, 2.08 and $2.40 \mathrm{~m}$ ) and three replicate units at each point. A statistical analysis was performed to find differences between the treatments, by means of a Kruskal-Wallis analysis followed by a Mann-Whitney median contrast for the color and turbidity variables. The data were analyzed with the statistical package STATGRAPHICS 7.0MR.

\section{RESULTS AND DISCUSSION}

\subsection{Retention time, degradation rates and kinetic coefficient}

In this study, the HW-CW was designed to operate with 200 L/day [14]; nevertheless, the average operating expense was $204 \pm 66 \mathrm{~L} /$ day, finding that if it operates more than $200 \mathrm{~L} /$ day, the HRT decreases, so the wastewater does not comply with the contact time between microorganisms and vegetation presenting low degradation. The HRT was 4.5 days, fulfilling the recommended design criteria $[2,13,15,19]$. The removal of BOD is achieved in a biological and physical way mainly under anaerobic-facultative conditions, and it is influenced by temperature, which was $27^{\circ} \mathrm{C}$ on average with an estimated $k$ of -0.43 days ${ }^{-1}$ [15]. To comply with NOM-001-SEMARNAT-1996, which indicates a daily discharge average of $75 \mathrm{mg} / \mathrm{L}$ of BOD [20], HRT was monitored at the 4th day. With a 6-day HRT, removals of more than $90 \%$ are achieved (Table 2) and comply with more stringent criteria set by the regulations for the protection of aquatic life in Mexico [20]. Similar results were reported in a study that concluded that an HRT of 8 days is adequate for the removal of organic matter 
Table 2: Estimation of the kinetic degradation constants in the HF-CW-Thalia geniculata.

\begin{tabular}{ccccc}
\hline Monitored days & BOD influent $(\mathrm{mg} / \mathrm{L})$ & BOD effluent $(\mathrm{mg} / \mathrm{L})$ & $k\left(\right.$ days $\left.^{-1}\right)$ & $\eta(\%)$ \\
\hline 1 & 375.50 & 66.20 & -0.39 & 82.4 \\
2 & 369.40 & 65.30 & -0.39 & 82.3 \\
3 & 403.20 & 66.50 & -0.40 & 82.5 \\
4 & 437.10 & 65.90 & -0.42 & 84.9 \\
5 & 391.70 & 43.30 & -0.49 & 88.9 \\
6 & 407.70 & 29.50 & -0.58 & 92.8 \\
7 & 254.20 & 50.50 & -0.36 & 80.1 \\
Average & 376.97 & 55.31 & -0.43 & 85.3 \\
\hline
\end{tabular}

at temperatures above $25^{\circ} \mathrm{C}$ [21], although this implies larger reactors. The kinetic degradation behaved as first order (Table 2). The removal efficiency of the maximum BOD was $92.8 \%$, the average was $85 \%$ and the minimum was $80 \%$, considering that the HW-CW is not operating in series as commonly established in treatment trains [13,22]. The current results complied with the quality water parameters to discharge into rivers with urban public use (75 $\mathrm{mg} / \mathrm{L})$, and in some days, it meets the aquatic life protection limits (30 mg/L) (Table 2) [20].

Another vegetation species has achieved similar efficiencies of BOD removal in a VF-CW. Also, BOD removals greater than 90\% were reported with Typha and Phragmites [23], and removal efficiencies with $80 \%$ were obtained with Typha and Phragmites after the second year of operation in an HF-CW [24]. In this study, Thalia geniculata achieved an 85\% BOD removal due to the fact that the organic matter is degraded aerobically and anaerobically by the bacteria adhered to the roots of the plants and to the support medium [25]. The most important effects of emerging macrophytes in wastewater treatment are the following: plant tissue, wind speed reduction that supports the sedimentation of suspended solids, filtering effect or adherence of microorganisms and the absorption of plants that can be a significant route for the elimination of nutrients, especially in low loading rates [26]. It is important to point out that the most important elements in the evaluation of macrophytes in CW are the removal of the basic contaminants of water, their easy handling and obtaining, as well as the sufficient abundance of the raw material in the region for possible repopulations in the maintenance of wetlands. The differences between the roots in each macrophyte species in the CW have a clear effect in the absorption of nutrients or basic contaminants, so it is consistent with the literature; the more the long roots are, the more absorption occurred.

\subsection{Spatial distribution of pollutants in the HF-CW}

In the $\mathrm{pH}$ values, minimal differences are observed in the spatial distribution because the input values are slightly alkaline (8.9-8.4) (Fig. 3), and there is also an effect of ion release by the substrate and the biofilm [27]. The temperature varies from inlet to outlet from $25.9^{\circ} \mathrm{C}$ to $26.6^{\circ} \mathrm{C}$ (Fig. 4), and this favors the growth and stabilization of mesophilic microorganisms [28]. The electrical conductivity decreases from 1,700 to $1,400 \mu \mathrm{S} / \mathrm{cm}$ and complies with the specification for agricultural irrigation in Mexico (Fig. 5). The system reduced the salinity of the wastewater so it is suitable to be used for the irrigation of crops [29]. The apparent color decreases from 800 to 200 Color Units (CU), with $86.7 \%$ being removed (Figs. 6 and 9), and the turbidity decreased from influent to effluent, being the 
Thalia geniculata effective in the removal of 90.3\% (Figs. 7, 8 and 9). Finally, the bacterial biomass in the support medium shows that the concentration of microorganisms from influent to effluent decreases gradually, from 33,000 to $2,000 \mathrm{mg} / \mathrm{kg}$ ( $\mathrm{mg}$ of biomass on $\mathrm{kg}$ of support medium). The support medium had a diameter of $2.8 \pm 0.8 \mathrm{~cm}$, porosity of $n=$ $56.3 \pm 3.5$ and density of $1,666.7 \pm 119.3 \mathrm{~kg} / \mathrm{m}^{3}$.

The basic parameters of pollutants monitored in the wastewater for the spatial distribution analysis can be seen in Table 3 .

Table 3. Basic pollutant parameters measured in wastewater for the HF-CW. Average data of two daily samples are presented, each one with 11 samplings.

\begin{tabular}{lccccccc}
\hline Points & $\mathrm{X}(\mathrm{m})$ & $\mathrm{Y}(\mathrm{m})$ & $\mathrm{pH}(\mathrm{UpH})$ & Temp. $\left({ }^{\circ} \mathrm{C}\right)$ & $\mathrm{CE}(\mu \mathrm{s} / \mathrm{cm})$ & Color $(\mathrm{CU})$ & Turb. $(\mathrm{NTU})$ \\
\hline M1 & 0.10 & 0.42 & 8.77 & 26.63 & $1,731.82$ & 861.59 & 25.19 \\
M2 & 0.60 & 0.42 & 8.91 & 26.58 & $1,691.36$ & 751.82 & 21.33 \\
M3 & 1.10 & 0.42 & 8.93 & 26.09 & $1,677.00$ & 549.05 & 16.10 \\
M4 & 0.10 & 1.25 & 8.62 & 26.25 & $1,603.59$ & 438.68 & 11.16 \\
M5 & 0.60 & 1.25 & 8.62 & 26.15 & $1,573.50$ & 367.59 & 9.27 \\
M6 & 1.10 & 1.25 & 8.59 & 25.90 & $1,507.45$ & 332.14 & 7.48 \\
M7 & 0.10 & 2.08 & 8.61 & 26.16 & $1,469.05$ & 267.68 & 5.99 \\
M8 & 0.60 & 2.08 & 8.56 & 26.18 & $1,440.64$ & 250.55 & 4.80 \\
M9 & 1.10 & 2.08 & 8.49 & 26.07 & $1,406.41$ & 230.64 & 4.15 \\
\hline
\end{tabular}
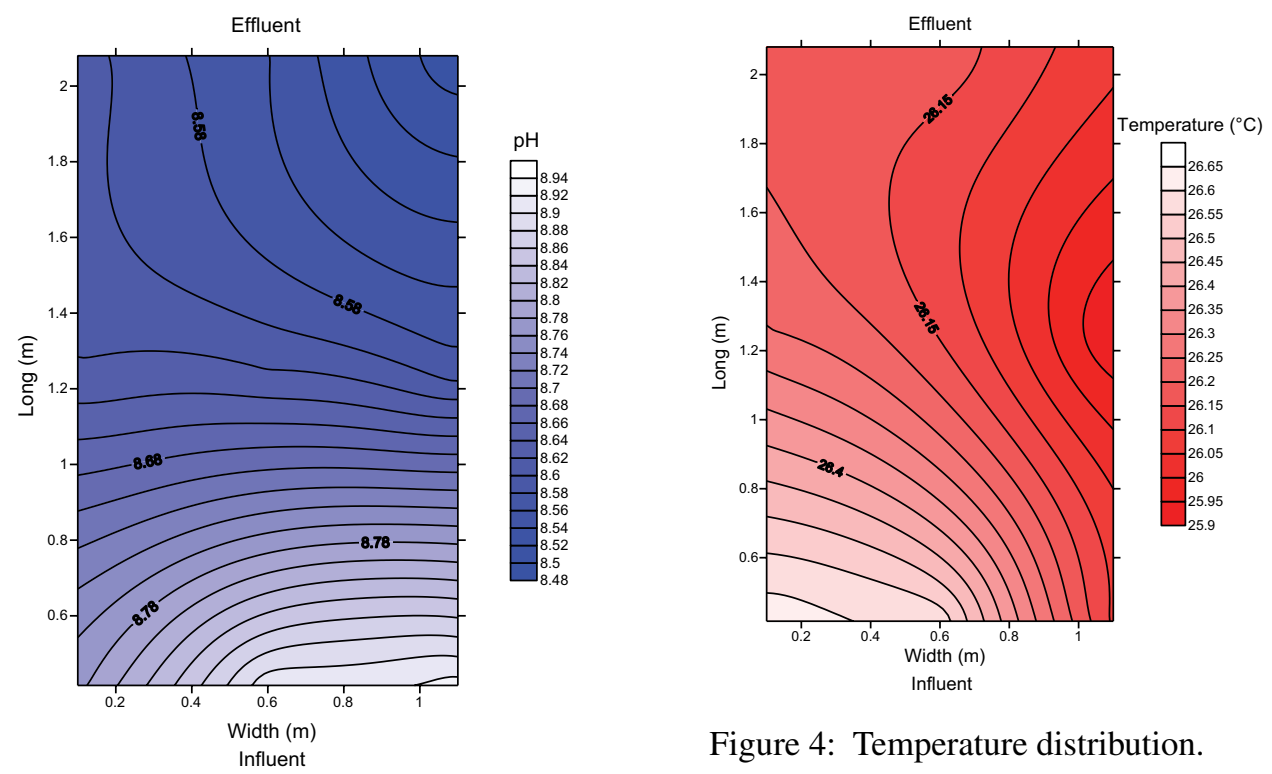

Figure 4: Temperature distribution.

Figure 3: $\mathrm{pH}$ distribution. 


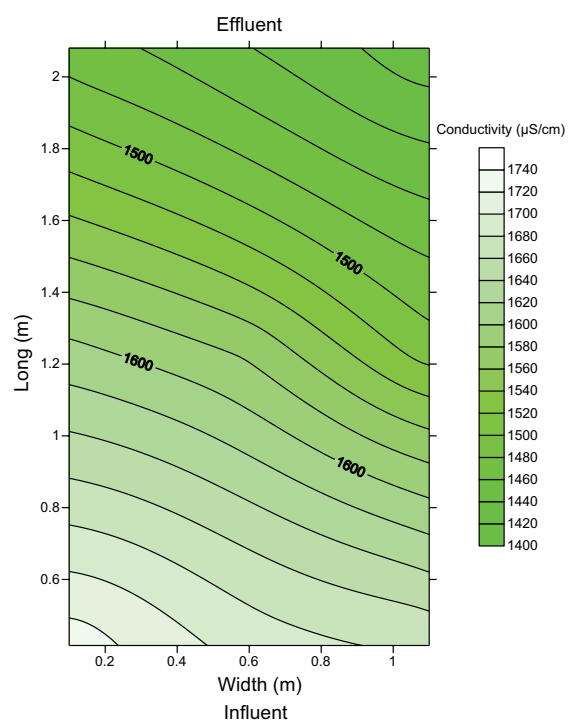

Figure 5: Distribution of EC.

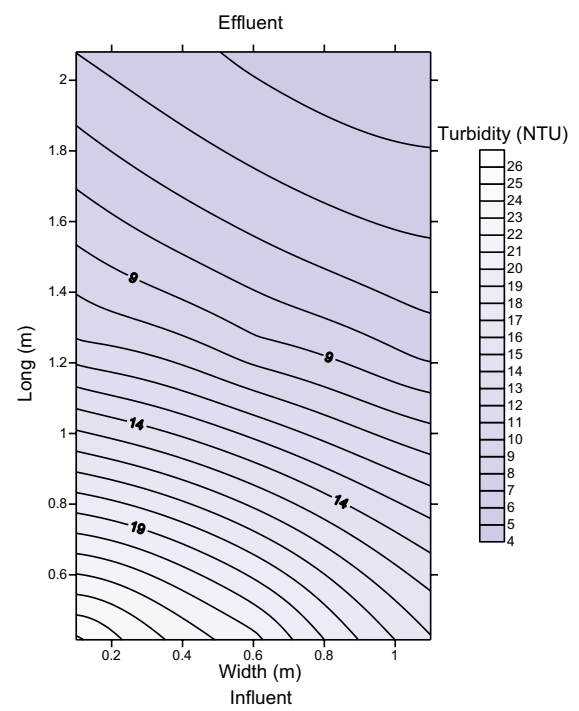

Figure 7: Turbidity distribution.

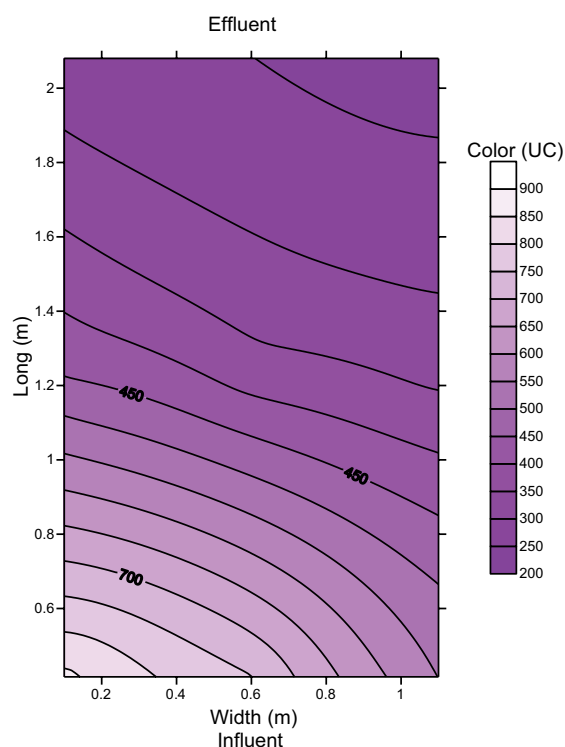

Figure 6: Distribution of color.

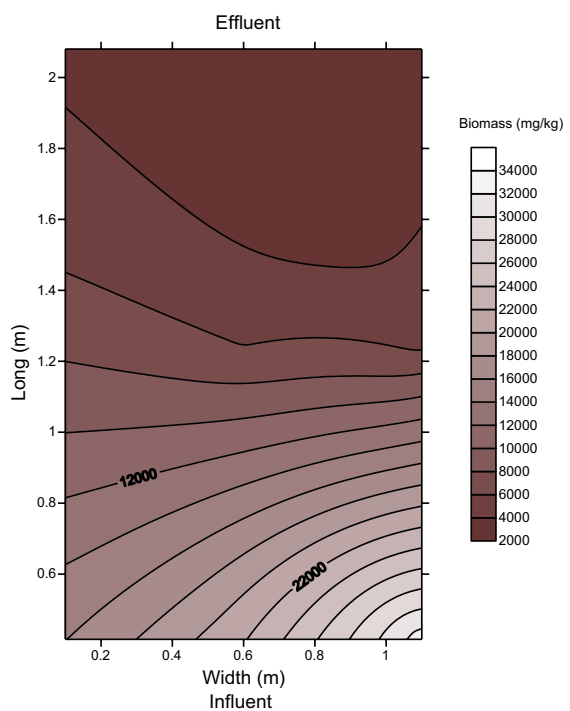

Figure 8: Distribution of biomass. 


\subsection{Removal efficiency of basic pollutants}

Regarding the removal efficiency of control parameters, it was observed that there is a degree of removal or stabilization in some cases. For the $\mathrm{pH}$ values, the HF-CW with Thalia geniculata presented an efficiency of $11.8 \%$, that is to say that the water enters slightly alkaline and low without leaving the moderately alkaline range. This value fulfilled the Mexican normativity, since the discharge ranges from 5 to 10 [20]. The temperature shows an efficiency of $7.2 \%$, achieving a reduction of $\sim 1^{\circ} \mathrm{C}$. It is mentioned that the temperature is basically the energy balance of the $\mathrm{CW}$ because it regulates the microbiological processes, and typically, the CWs have two thermal regions (entry and exit) where the temperature basically adjusts to the environmental conditions [30]. In the removal of electrical conductivity, an efficiency of $27.6 \%$ was obtained, and this parameter gives us an estimate of the concentration of mineral salts present, useful in agriculture [30]. Salts and other substances affect the quality of the wastewater, influencing the aquatic biota since each organism can tolerate certain salinity values. A low $\mathrm{CE}$ avoids problems due to phytotoxicity in the vegetation [31]. In terms of color in the wastewater, $86.7 \%$ was removed and can be attributed to the characteristics of the Thalia geniculata as it requires more organic matter and nutrients for its growth. The colloidal matter prevents the transmission of light, and the greater turbidity is associated with the particle size: the smaller the particle size, the greater the turbidity of the water. A high turbidity in the residual water can affect the purification process in the following way: protecting the pathogenic microorganisms from the effects of disinfection by the action of sunlight; stimulating the proliferation of bacteria; and decreasing the capacity of photosynthesis of aquatic plants and zooplankton [32]. Therefore, it is of great importance to reduce the concentrations of this parameter; so in this treatment with Thalia geniculata, $90.3 \%$ of the turbidity was removed (Table 4).

\subsection{Mathematical approximation and statistical analysis of color and turbidity}

In order to better understand the removal of contaminants in an HF-CW with Thalia geniculata, the mean concentration in the reactor was evaluated longitudinally according to the main control parameters that indirectly indicate the removal of TSS and BOD, such as turbidity and color. The color evaluation showed a decreasing behavior as the water passes through the HF-CW at different distances (Fig. 10), where it is observed that the influent has an initial concentration of 1,621 UC and lowers this concentration in the effluent to $203 \mathrm{UC}$, according to an exponential mathematical model with negative slope establishing the equation $y=$ $2,144.7 \mathrm{e}^{-0.519 \times}$, with an $R^{2}=0.9341$. The statistical analysis of the available color, after testing

Table 4: Efficiency of removal of basic contaminants in the HF-CW.

\begin{tabular}{lrrrr}
\hline Parameter & Influent & Effluent & $\eta(\%)$ & $S D \pm$ \\
\hline $\mathrm{pH}(\mathrm{U} \mathrm{pH})$ & 9.51 & 8.39 & 11.8 & 3.4 \\
Temperature $\left({ }^{\circ} \mathrm{C}\right)$ & 28.01 & 25.99 & 7.2 & 4.8 \\
$\mathrm{CE}(\mu \mathrm{s} / \mathrm{cm})$ & $1,754.99$ & $1,270.18$ & 27.6 & 14.8 \\
Color $(\mathrm{CU})$ & $1,751.41$ & 232.50 & 86.7 & 6.8 \\
Turbidity (NTU) & 33.02 & 3.21 & 90.3 & 5.8 \\
\hline
\end{tabular}




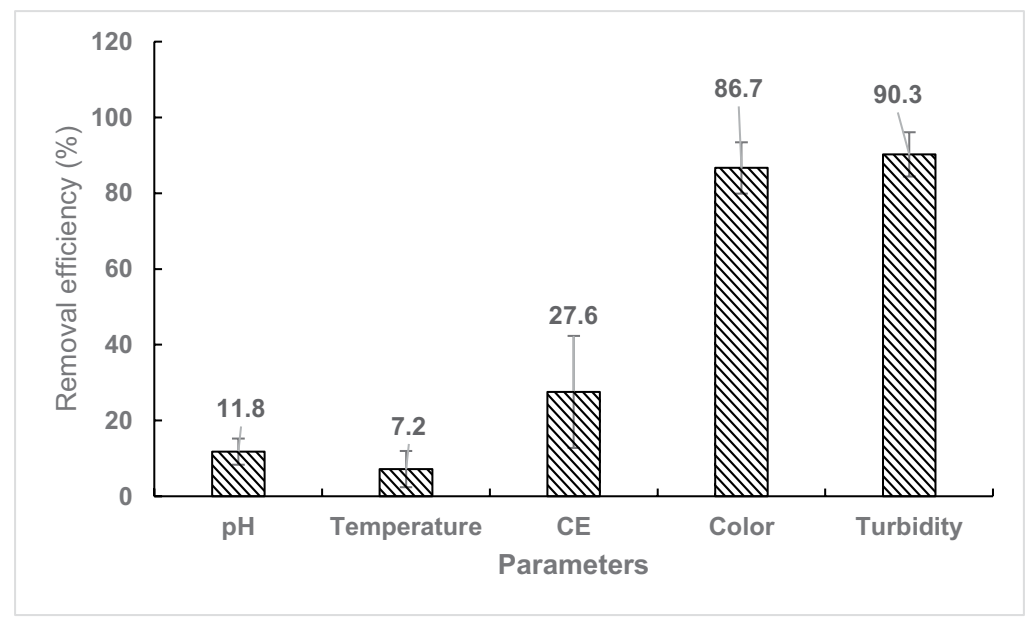

Figure 9: Removal efficiency of basic parameters.

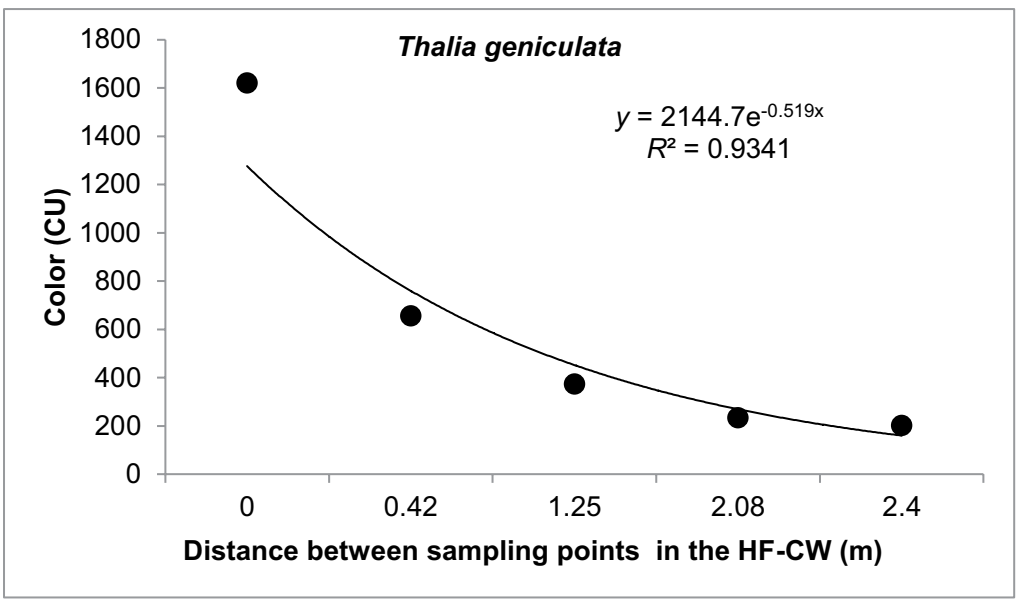

Figure 10: Longitudinal behavior of color through the HF-CW.

if the data were normal and hosed, was done. A Kruskal-Wallis test was performed to evaluate the hypothesis that the medians of color (UC) within each of the five levels of distance (m) are the same. Since the $P$-value is less than 0.05 , there is a statistically significant difference between the medians with a $95.0 \%$ confidence level (Fig. 11).

The turbidity values showed a decreasing behavior as the water passes through the HF-CW at the different distances (Fig. 12). It was observed that the influent has an initial concentration of $31.5 \mathrm{NTU}$ and decreasing in the effluent (2.8 NTU) according to an exponential mathematical model with negative slope establishing the equation $y=59.873 \mathrm{e}^{-0.614 x}$, with an $R^{2}=$ 0.9972. The Kruskal-Wallis test evaluates the hypothesis that the turbidity medians (NTU) within each of the five distance levels $(\mathrm{m})$ are equal. Since the $P$-value is less than 0.05 , there is a statistically significant difference between the medians with a $95.0 \%$ confidence level (Fig. 13). 


\section{Gráfico Caja y Bigotes}

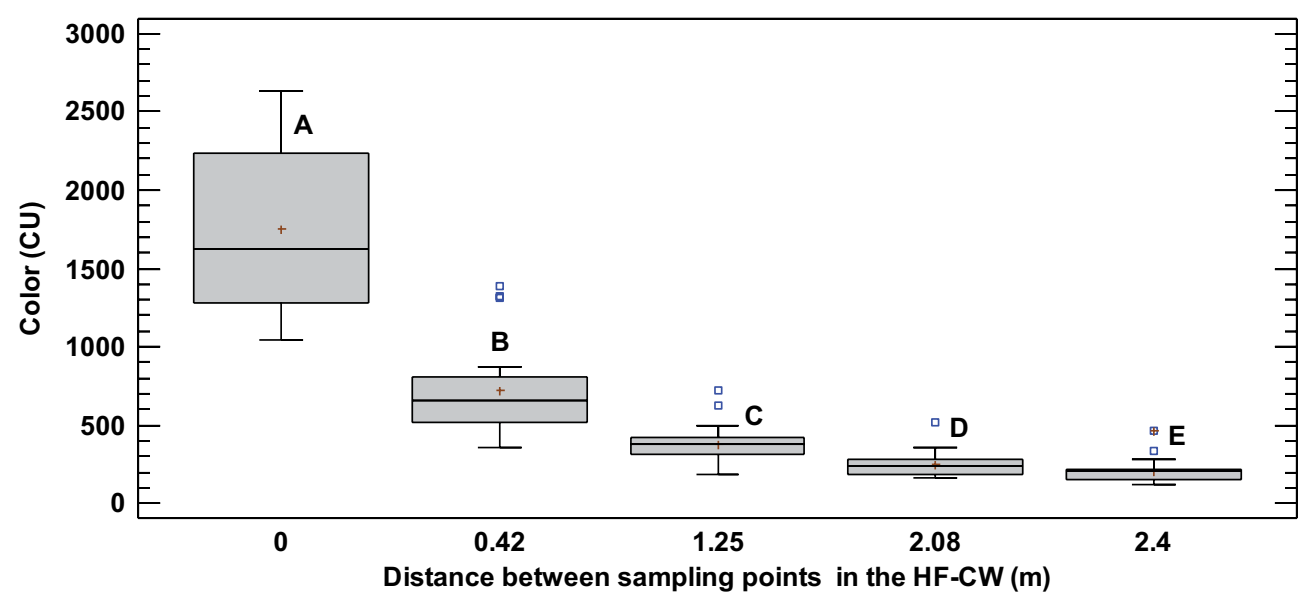

Figure 11: Mean values $( \pm \mathrm{SD})$ of color at different $\mathrm{CW}$ treatments. Different letters indicate statistically significant differences between treatments.

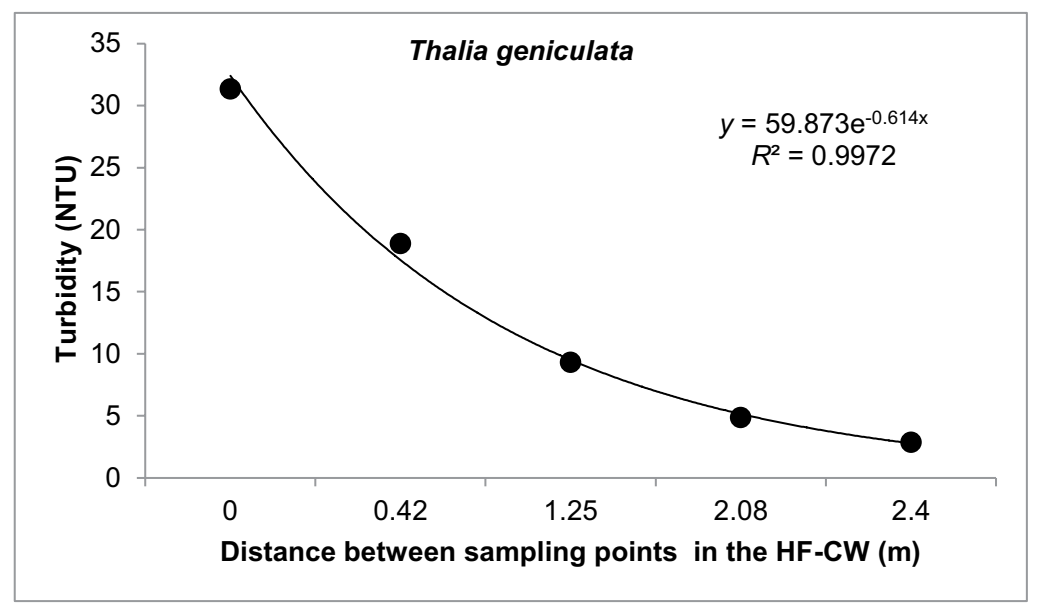

Figure 12: Longitudinal behavior of turbidity in the HF-CW.

\subsection{Vegetation characteristics}

The growth of Thalia geniculata vegetation can vary according to the climatic conditions of the area where the $\mathrm{CW}$ is installed. One of the main parameters that influence vegetation growth is the environmental temperature and the amount of organic matter available in the wastewater $[33,35]$. The physical variables monitored in Thalia geniculata at the end of the evaluation period showed the following average values with their standard deviation: The plant had a height of $303.3 \pm 20.53 \mathrm{~cm}$, pseudostem diameter of $7.3 \pm 0.43 \mathrm{~cm}$ and perimeter of $19.1 \pm 2.68 \mathrm{~cm}$; the diameter of the petiole was $1.4 \pm 0.39 \mathrm{~cm}$ and the leaf blade with width and length of $21.7 \pm 0.92 \mathrm{~cm}$ and $71.5 \pm 2.98 \mathrm{~cm}$, respectively. The population density was 
Gráfico Caja y Bigotes

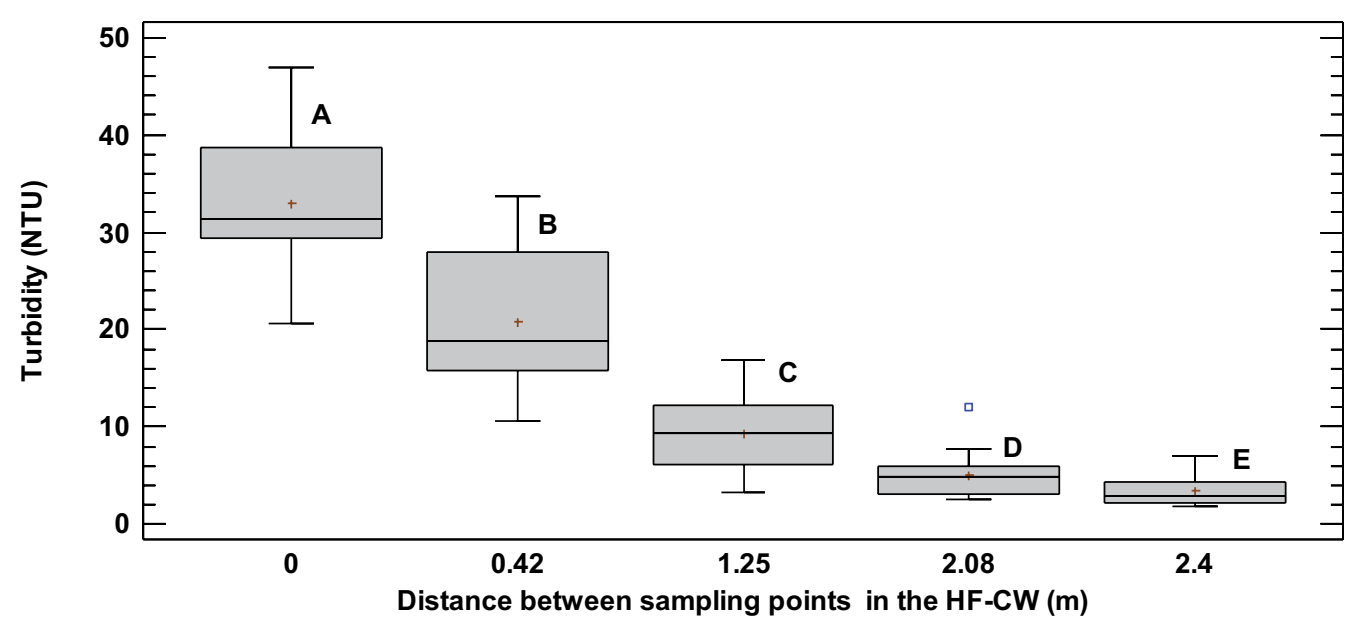

Figure 13: Mean values $( \pm \mathrm{SD})$ of turbidity at different $\mathrm{CW}$ treatments evaluated. Different letters indicate statistically significant differences between treatments.

$3.6 \pm 1.02$ young shoots $/$ plants $/ \mathrm{m}^{2}$ and $3.5 \pm 0.93$ adult plants $/ \mathrm{m}^{2}$. It is important to remember that it started with eight individuals per $\mathrm{m}^{2}$. In general, each plant presented a weight of $1.031 .1 \pm 260.93 \mathrm{~g} / \mathrm{m}^{2}$, and at the end of the period, the weight recorded was $5.004 .2 \pm$ $1.113 .04 \mathrm{~g} / \mathrm{m}^{2}$. It represents that they almost gained five times more biomass. The humidity contained in the Thalia geniculata plant was on average $68 \pm 8 \%$, recovering $22.4 \pm 2.8 \mathrm{~kg}$ (dry basis) of vegetable biomass by pruning in the maintenance.

Emerging macrophyte vegetation in the treatment of wastewater offers advantages in the biomass of the plant tissue; reduces wind speed, thus favoring the sedimentation of solids in suspension; and offers a filtering effect, adherence of microorganisms and absorption of nutrients in plants [26]. Therefore, Thalia geniculata is considered to be efficient and highly recommended for wastewater treatment.

\section{CONCLUSIONS}

The present study showed that the use of Thalia geniculate, as a native vegetation in an HF-CW, has the capacity to synthesize and assimilate the organic matter and nutrients in domestic wastewater. In order to achieve the adaptation process to the support medium (gravel), a stabilization stage was applied during four months showing rapid growth and spread. Likewise, the support medium allowed the adherence of microbial biomass in concentrations of $34,000 \mathrm{mg} / \mathrm{kg}$ with a porosity of $n=56.3 \pm 3.5$ and a density of 1,666.7 \pm $119.3 \mathrm{~kg} / \mathrm{m}^{3}$. From the experimental results, Thalia geniculata was found to be quite efficient for the wastewater treatment in a subsurface flow with $85 \%$ of BOD removal. At ambient temperatures higher than $28^{\circ} \mathrm{C}$, a $k$ of -0.43 days $^{-1}$ was calculated, improving the efficiency similar to that of a secondary treatment.

The spatial and longitudinal distribution of the pollutants was determined within the HF-CW. The point where purification began was identified along the HF-CW. The plants located at the beginning of the reactor synthesized the greatest amount of contaminant, 
showing its growth and rapid propagation in the same way that the concentration of microorganisms is reflected. This analysis of the physical behavior of the reactor is also a tool that can be used to identify possible process and short circuit decontrol of the system.

\section{REFERENCES}

[1] Helmer, R. \& Hespanhol, I., Water Pollution Control, 1st ed. WHO, UNEP: Great Britain, 1997. https://www.who.int/water_sanitation_health/resourcesquality/wpcbegin. pdf. Retrieved on June 13, 2019.

[2] USEPA., Office of Research and Development Cincinnati, Ohio, EPA/625/R-99/010, Design Manual: Constructed wetlands treatment of municipal wastewater, September 2000.

[3] Ayaz, S.C. \& Akca, L., Treatment of wastewater by natural systems. Environment International, 26(3), pp. 189-195, 2001. https://www.academia.edu/27567939/Treatment_ of_wastewater_by_natural_systems. Retrieved on June 13, 2019.

[4] Song, Z., Bi, X. \& Cao, J., Application of constructed wetlands in sewage treatment in small cities in China. Chinese Journal of Ecology, 22(3), pp. 74-78, 2002.

[5] Mantovi, P., Marmiroli, M., Maestri, E., Tagliavini, P.S. \& Marmiroli, N., Application of a horizontal subsurface flow constructed wetland on treatment of dairy parlor wastewater. Bioresource Technology, 88(2), pp. 85-94, 2003. https://europepmc.org/abstract/ med/12576000. Retrieved on June 13, 2019.

[6] Burgoon, P.S., DeBusk, T.A., Reddy, K.R. \& Koopman, B., Vegetated submerged beds with artificial substrates. I: BOD removal. Journal of Environmental Engineering, 117(4), pp. 394-407. file:///C:/Users/User/Documents/MANUALES, \%20LIBROS\%20 Y\%20ARTICULOS\%20PARA\%20CONSULTA/163.Vegetated\%20submerged $\% 20$ beds.pdf. Retrieved on June 13, 2019.

[7] Guodong, J., Sun, T., Zhou, Q., Sui, X., Chang, S. \& Li, P., Constructed subsurface. Ecological Engineering, 18, pp. 459-465, 2002.

[8] Wei, L., Wu, Z.-B., Cheng, S.-P., Zhou, Q.-H. \& Hu, H.-Y., Roles of substrate microorganisms and urease activities in wastewater purification in a constructed wetland system. Ecological Engineering, 21, pp. 191-195, 2003. DOI: 10.1016/j.ecoleng.2003.11.002.

[9] Ramos, E.M.G., Rodríguez, S.L.M. \& Martínez, C.P., Uso de macrófitos acuáticas en el tratamiento de aguas para el cultivo de maíz y sorgo. Hidrobiología, 17(1 suplemento), pp. 7-15, 2007. http://www.scielo.org.mx/scielo.php?script=sci_arttext\&pid $=$ S0188-88972007000400002. Retrieved on June 13, 2019.

[10] Ong, S.A., Uchiyama, K., Inadama, D. \& Yamagiwa, K., Simultaneous removal of color, organic compounds and nutrients in azo dye-containing wastewater using upflow constructed wetland. Journal of Hazardous Materials, 165, pp. 696-703, 2009. https://www.ncbi.nlm.nih.gov/pubmed/19081183. Retrieved on June 13, 2019.

[11] Grafias, P., Xekoukoulotakis, N.P., Mantzavinos, D. \& Diamadopoulos, E., Pilot treatment of olive pomace leachate by vertical-flow constructed wetland and electrochemical oxidation: An efficient hybrid process. Water Research, 44, pp. 2773-2780, 2010.

[12] Comisión Nacional del Agua (CONAGUA), Inventario Nacional de Plantas Municipales de Potabilización y de Tratamiento de Aguas Residuales en Operación. Subdirección General de Agua Potable, Drenaje y Saneamiento, Diciembre 2016, 2015. https:// www.gob.mx/cms/uploads/attachment/file/197610/Inventario_2015.pdf. Retrieved on June 13, 2019.

[13] Secretaria de Medio Ambiente y Recursos Naturales (SEMARNAT) y Comisión Nacional del Agua (CONAGUA), Manual de Agua Potable, Alcantarillado y Saneami- 
ento. Diseño de Plantas de Tratamiento de Aguas Residuales Municipales: Humedales Artificiales. Subdirección General de Agua Potable, Drenaje y Saneamiento, ISBN: 978-607-626-010-4, 2015, http://aneas.com.mx/wpcontent/uploads/2016/04/SGAPDS-1-15-Libro30.pdf. Retrieved on June 13, 2019.

[14] López Ocaña, G., Torres Balcázar, C.A., Bautista Margulis, R.G., Hernández Barajas, J.R., Gutiérrez Vidal, J.J., de la Cruz Luna, E. \& Ferrer Sánchez, M.I., Diseño de sistemas experimentales de humedales artificiales de flujo libre y subsuperficial. Perspectiva Científica desde la UJAT. Editorial UJAT. Tabasco, Mexico., ISBN: 978-607-606-1725, pp. 133-146, 2014. http://www.archivos.ujat.mx/2014/divulgacion\%20cientifica/ SDDC2013final.pdf.

[15] Crites, R.W. \& Tchobanoglous, G., Small and Decentralized Wastewater Management Systems, McGraw Hill Co.: New York, NY, 2000.

[16] Chung, A.K.C., Wu, Y., Tam, N.F.Y. \& Wong, M.H., Nitrogen and phosphate mass balance in a sub-surface flow constructed wetland for treating municipal wastewater. Ecological Engineering, 32, pp. 81-89, 2008, available at http://dx.doi.org/10.1016/j. ecoleng.2007.09.007.

[17] McCabe, W.L., Smith, J.C. \& Harriot, P., Operaciones Unitarias en Ingeniería Química, Cuarta Edición. 1991. Madrid.

[18] Surfer 8.0. Powerful Contouring, Gridding, and 3D Surface Mapping Software for Scientists and Engineers. Surfer® Software. E-mail info@ssg-surfer.com.

[19] Kivaisi, A.K., The potential for constructed wetlands for wastewater treatment and reuse in developing countries: A review. Ecological Engineering, 16, pp. 545-560, 2000. DOI: 10.1016/S0925-8574(00)00113-0.

[20] NOM-001-SEMARNAT-1996, Que establece los límites máximos permisibles de contaminantes en las descargas de aguas residuales en aguas y bienes nacionales. Secretaría de Medio Ambiente, Recursos Naturales y Pesca. Diario Oficial de la Federación. 23 de Abril de 2003.

[21] Akratos, S.C. \& Tsihrintzis, A.V., Effect of temperature, HRT, vegetation and porous media on removal efficiency of pilot-scale horizontal subsurface flow constructed wetlands. Ecological Engineering, 29, pp. 173-191, 2007, available at http://dx.doi. org/10.1016/j.ecoleng.2006.06.013.

[22] Jiménez-López, E.C., López-Ocaña, G., Bautista-Margulis, R.G., Castelán-Estrada, M., Guerrero-Peña, A., Hernández-Barajas, J.R., Torres-Balcázar, C.A., de la CruzLuna, E. \& Romellón-Cerino, M.J., Solís-Silvan, wastewater treatment by constructed wetlands with Thalia geniculata and Paspalum paniculatum in a tropical system of Mexico. The International Journal of Sustainable Development and Planning, 12(1), pp. 42-50, 2017. DOI: 10.2495/SDP-V12-N1-42-50.

[23] Morari, F. \& Giardini, L., Municipal wastewater treatment with vertical flow constructed wetlands for irrigation reuse. Ecological Engineering, 35, pp. 643-653, 2009, available at http://dx.doi.org/10.1016/j.ecoleng.2008.10.014. Retrieved on June 13, 2019.

[24] Solano, M.L., Soriano, P. \& Ciria, M.P., Constructed wetlands as a sustainable solution for wastewater treatment in small villages. Biosystem Engineering, 87(1), pp. 109-118, 2004. DOI: 10.1016/j.biosystemseng.2003.10.005.

[25] Abidi, S., Kallali, H., Jedidi, N., Bouzaiane, O. \& Hassen, A., Comparative pilot study of the performances of two constructed wetland wastewater treatment hybrid systems. Desalination, 246, pp. 370-377, 2009, available at http://dx.doi.org/10.1016/j.desal.2008.03.061. Retrieved on June 13, 2019. 
[26] Vymazal, J., Emergent plants used in free water surface constructed wetlands: A review. Ecological Engineering, 61, pp. 582-592, 2013, available at http://dx.doi.org/10.1016/j. ecoleng.2013.06.023. Retrieved on June 13, 2019.

[27] Kadlec, R.H. \& Knight, R. Treatment Wetlands, Lewis Publishers: Boca Raton, FL, 1996.

[28] Silva, J., Torres, P. \& Madera, C., Reuso de aguas residuales domésticas en agricultura: Una revisión. Agronomía Colombiana, 2, pp. 347-359, 2008. https://revistas.unal.edu. co/index.php/agrocol/article/view/13521/14204. Retrieved on June 13, 2019.

[29] Kadlec, R.H. 2009. Comparison of free water and horizontal subsurface treatment wetlands. Ecological Engineering, 35, pp. 159-174. https://doi.org/10.1016/j.ecoleng.2008.04.008. Retrieved on June 13, 2019.

[30] Seoánez, M., Aguas residuales, Mundi-Prensa: Madrid, 61 p., 1999.

[31] Barbaro, L.A., Karlanian, M.A. \& Mata, D.A., Importancia del pH y la Conductividad Eléctrica (CE) en los sustratos para plantas. Argentina: Instituto Nacional de Tecnologías Agropecuarias, pp. 7-8, 2014.

[32] Marcó, L., Azario, R., Metzler C y Garcia, M.C. La turbidez como indicador básico de calidad de aguas potabilizadoras a partir de fuentes superficiales. Hig. Sanid. Ambient., 4, pp. 72-82, 2004.

[33] Delgadillo, O., Camacho, A., Pérez, F. \& Andrade, M., Depuración de aguas residuales por medio de humedales artificiales. Bolivia: Centro Andino para la Gestión y Uso del Agua (Centro AGUA) Cochabamba, 2010.

[34] APHA., Standard Methods for Examination of Water and Wastewater, Washington, DC: American Public Health Association WWA, 2001.

[35] López-Ocaña, G., Bautista-Margulis, G., Ramos Herrera, S., Torres-Balcazar, C.A., López-Vidal, R. \& Pampillón-González, L., Phytoremediation of wastewater with Thalia Geniculata in constructed wetlands: Basic pollutant distribution. WIT Transactions on Ecology and the Environment, Vol. 228, WIT Press, 2018, ISSN 1743-3541. Great Britain. DOI: 10.2495/WP1871. 